\title{
Avaliação da Viabilidade de Cultura Probiótica em Calda Para Sorvete
}

\author{
Gilson Parussolo (I), Edi Franciele Ries (I), Patche Helena Michel \\ (I), Vanessa Pires da Rosa (I), Patrícia Fernanda Schons (I), \\ Janaina Schmitt (I), Rita Bussato (I)
}

(I) UFSM - Universidade Federal de Santa Maria (Linha Sete de Setembro, s/n - BR 386 - Km 40)

\section{Resumo}

No mercado nacional, os micro-organismos probióticos estão aplicados a diversos tipos de alimentos. Para o desenvolvimento de um alimento contendo bactérias probióticas, devem ser considerados vários fatores, tais como, atividade de água, temperatura de processamento e armazenamento, tempo de estocagem, entre outros de forma que a cultura probiótica permaneça viável e em número elevado durante a vida de prateleira do produto. O objetivo do trabalho foi avaliar diferentes metodologias para maior viabilidade de cultura probiótica Lactobacillus acidophylus NCFM em calda base para aplicação no desenvolvimento de sorvete simbiótico. A calda base para sorvete foi preparada conforme três tratamentos.

Tratamento 1: Foi adicionado o inóculo sem ativação na calda base, na concentração de $0,05 \%$. Tratamento 2: Foi realizada ativação da cultura em um pré-inóculo com $40 \mathrm{~mL}$ de leite UHT integral mais $8 \mathrm{~g}$ de leite em pó e esterilizado em autoclave a $121^{\circ} \mathrm{C}$ por 15 minutos, a viabilidade da cultura foi avaliada na calda antes do congelamento. Tratamento 3: A calda foi preparada e incubada para ativação conforme descrito no Tratamento 2 , a qual foi congelada a $-18^{\circ} \mathrm{C}$ por 4 dias, sendo a análise realizada após o congelamento. A análise microbiológica para ver a viabilidade foi realizada em meio MRS com incubação em jarra de anaerobiose por 96 horas à $37^{\circ} \mathrm{C}$. No tratamento 3, verificou-se contagem equivalente ao tratamento 2, mostrando que o micro-organismo resistiu ao congelamento estando viável 
até a diluição 10-7. Já o tratamento 1 não foi tão eficiente quanto os tratamentos 2 e 3 , pois conforme as diluições, foi diminuindo a contagem do L. acidophylus NCFM, sendo assim eficiente a utilização da ativação da cultura probiótica antes da adição na calda do sorvete. A utilização do método de ativação da cultura probiótica é eficiente para que o microrganismo apresente elevada viabilidade após congelamento.

Palavras-Chave: Probiótico, viabilidade, frutanos Agência de Fomento: $\mathrm{CNPq}$ 